\title{
Active Learning Innovations in Knowledge Management Education Generate Higher Quality Learning Outcomes
}

\section{Arthur Shelley}

\begin{abstract}
Innovations in how a postgraduate course in knowledge management is delivered have generated better learning outcomes and made the course more engaging for learners. Course participant feedback has shown that collaborative active learning is preferred and provides them with richer insights into how knowledge is created and applied to generate innovation and value. The course applies an andragogy approach in which students collaborate in weekly dialogue of their experiences of the content, rather than learn the content itself. The approach combines systems thinking, learning praxis, and active learning to explore the interdependencies between topics and how they impact outcomes in real world situations. This has stimulated students to apply these ideas in their own workplaces.
\end{abstract}

Keywords: knowledge, learning, education, systems thinking, design thinking, active learning interdependence, wiki.

\section{Introduction}

Knowledge is a challenging concept to grasp and perhaps it is even more difficult to understand how and when to leverage it to create value. It is possible to have knowledge and get no benefit from it, just as it is possible to have knowledge and apply it in an incorrect manner or time to destroy value. The adage that "Knowledge is power" is true if one wants to secure political power over others. However, this is not an optimal approach to increasing performance and amplifying value. The perspective taken in the course described in this paper is "Knowledge is powerful, when shared and applied to generate sustainable mutual benefits."

Knowledge Management (KM) as a professional discipline has come a long way over the past few decades, evolving through several generations of focus and effectiveness (Lambe 2011). Whilst the practice of knowledge management is now applied very well in some high performing 
organisations (Cavaleri, Seivert \& Lee 2005; Malhotra, Majchrzak \& Rosen 2007; Shelley 2009), the practice of knowledge management education is still underperforming (Bedford 2013). Many KM courses remain focused on theoretical aspects within the context of a content-focused and teachercentered traditional teaching approach.

This is a less effective way to learn the importance of knowledge than engaging students to experience application of theoretical concepts to real problem solving (Albanese \& Mitchell 1993; Boud \& Feletti 1997) and to students' own work environment. Problem Based Learning (Hung, Jonassen \& Liu 2008) and Action Learning (Freeman et al. 2014; McIntosh 2010; Raelin 2006; Zuber-Skerritt 2002) are approaches that have been developed over time that can offer an alternative way for students to understand the concepts they are learning as they engage learners at a higher level of cognition than simply remembering facts (Bloom, Hastings \& Madaus 1971).

This paper describes how innovations to the way the course is facilitated have enhanced how KM education is facilitated for a Masters level course at RMIT University in Melbourne, Australia. Over a seven year period, students have been engaged in an evolving development process, in which they are contributors in the exploration of how we come to know what we know and how we can learn to do this more effectively. Together, they seek to discover how knowledge is fundamental to almost everything we do; how we make decisions; and what influences what we think we know. The course participants gain this understanding by exploring some fundamental questions:

- How does one learn how to optimally create and apply knowledge to make a difference?

- How can one be more effective in the application of knowledge at a personal, team and organisational level?

- How do we collaborate to generate richer insights and make better sense of the world?

- What is already known and how do I build onto that within my own contexts?

These questions are core challenges that many knowledge initiatives face. They are often the sources of barriers to success in knowledge strategies in corporations. They enable the participants to think about the theoretical concepts in pragmatic ways and help them to devise better ways to apply the theory into practice in order to generate desired outcomes. They shift the mindset of the learners from existing knowledge capture and storage to using knowledge to generate value and stimulate cycles of knowledge creation. That is, they generate a demand for knowledge rather than just create a reservoir of knowledge - the latter has been the focus of many failed 
KM programs (Chua \& Lam 2005; Edmondson 2011; Mosier \& Fischer 2011; Müller \& Turner 2010).

\section{Case background}

This research reports on a case study in which the evolution of a postgraduate course in knowledge management has been an innovative, emergent and social process between the learning facilitator and cycles of course participants over a period of seven years. The evidence for the case involves collation of qualitative and semi-qualitative information to enhance the learning experiences in the course, originally called Knowledge Management, but changed to Knowledge Driven Performance (KPD) to reflect the true sense of the course as the emphasis and context changed.

In 2007, before the current course coordinator (and author of this paper) arrived, the course received poor feedback. It was judged by students as very content-focused, highly theoretical and not relevant to their professional development. The author, a knowledge practitioner working in industry at the time, was asked to redevelop the course to provide greater value to the students. The course was restructured to be highly collaborative and applied, based on learning literature and the author's experiences in engaging people in knowledge management initiatives in industry.

Aspects of this course that make it quite different from traditional content-based education include:

- It focuses on knowledge creation and application to generate value in real organisations.

- It is highly interactive and conversational about the sense and meaning of content in the context of the students, not about the content itself.

- Learning interactions are student-centred, emergent and social (as opposed to teacher led, rigid and content focused).

- All students can see the assignment submissions of all other students as they are generated through a collaborative wiki, where they connect their own research to other students' work through hyperlinks.

- Students are actively encouraged to help others but not permitted to actually change their peers' submissions. This happens through suggestions made in comments offered at the bottom of their wiki page (for which they get additional marks). The logic of this is that it prepares them for collaborative work in the workplace rather than reinforcing competitive behaviours.

- Grades are equally divided between group (40\%) and individual (40\%) work, with the remainder being for "collaborative participation" measured by supporting comments and contributions to discussions (face to face or on-line). 
- Group assignments are conducted as a knowledge audit of real high performing organisations. Students are required to find knowledge gaps and recommend knowledge-based initiatives to improve performance and return on investment. Assessment of the assignments is done through formal business proposals and role-play presentations to the "CEO" (learning facilitator) and "Board" (class peers) of the organisation to seek funding for their initiatives.

- Students participate in reflective exercises in most weeks where they are asked to provide insights on the topic of the week, related to their own contexts.

- There is a strong "praxis" approach. This means maintaining a balance between theory and practice so that neither is seen as master. Optimal results come from blending both to support sense-making, decision-making, actions and reflection to reinforce learning.

- Reflective practice activities are conducted throughout the course, focused on how students have applied what they have learnt in their workplaces and to give them experience in cycles of multiple-loop learning. This provides greater insights on the application of what they have learnt and how they might gain more in the next application.

- Feedback for assignment submissions is specific and provides a rich balance between strengths and weakness of the paper (regardless of the grade). Feedback is viewed as the most critical element to improve student learning outcomes over the duration of the course.

The KDP course is an elective unit for a Masters of Business Administration (MBA) that emphasises the interdependence of many of the topics covered across the rest of the MBA. It has been designed to engage students in collaborative and social learning to enrich the student learning experience. Rather than being taught content, they are encouraged to constructively challenge each other's perspectives around topics, readings and concepts, through conversations. Knowledge Driven Performance is offered as an elective once per year with student numbers ranging from 20 to 35 during the time of this study. The course is equivalent of a 12 credit point course in a Masters level program and is usually delivered as a three hour interaction once per week for twelve weeks. Originally it was only offered as a face to face class, but since 2011 it has also been offered as a virtual course through Open Universities Australia (OUA) once per year. Student enrolments in OUA range from 20 to 50 and weekly topics are stimulated with a video and standard course materials loaded onto the Learning Management System (LMS) and supported by discussion forums and interactions via the Collaborate (conferencing) tool or Skype.

The course is structured into 11 topics and one final report presentation at the end. These are typically facilitated in one three hour session per week for 12 weeks in both face-to-face and on-line formats. The order of 
topics (listed below) build like a jigsaw puzzle, starting with how knowledge informs strategy, through some theoretical concepts, then towards practical implications and how to apply them, and culminating in an integrative business proposal where the topics are brought together to enhance the performance of a real organisation (which may be their own workplace).

The order of course topics is:

- Foundations for Business Strategy: embedding knowledge principles into business practice.

- Making sense of a rapidly changing world: knowledge as the foundation of decision-making and future performance.

- Application of knowledge to create value: who has done this well?

- Conversations that Matter: interactive forum in which class participants discuss their individual topic with other students to generate dialogue around the links between knowledge related topics.

- Back to Basics: applying theories and approaches to enable improvement.

- Leveraging Intellectual Assets: process and governance.

- Leveraging Intellectual Assets: culture and structures.

- Support Tools: helping thinking people to be even more effective and efficient.

- Reflective Practice: understanding how reflection enhances learning.

- Sustained business continuity: integrating knowledge into the Learning Organisation

- Making a Difference: capabilities required for "Knowledge Leadership"

- Presentation of business proposals in a role play to "CEO" (teacher) and board (class).

Each week there is a brief coverage of the topic followed by activities to explore the topic, such as role plays, case studies, games or problems to resolve, videos to present challenges, and facilitated dialogue or reflections to share the ideas they have learned or applied in their workplace. The topics have a very pragmatic approach and leverage the knowledge in the room, thereby aligning with an andragogy learning approach (Knowles 1984; Knowles, Holton \& Swanson 2011). The case studies and assessments reinforce this through their requirement to demonstrate the application of theoretical concepts to deliver desired improvement outcomes.

Course participants collectively build a repository of relevant resources as each one researches a different topic and then is challenged to link their topic to as many of the other topics within the context of their article (through the collaborative wiki) and to highlight how their topic is influenced by knowledge. Marks are increased for adding supporting comments to other participants to reinforce the value of shared knowledge to increase quality for everyone. Example topics in the wiki assignment include; Leadership, 
Organisational learning, Ethics, Innovation, Capability development, Culture, Decision making, Succession, Induction, Data mining, Knowledge transfer, Codification, Community of practice, Mentoring, Sustainability, Complex adaptive systems, Reflective practice, Whistleblowing, Security, Knowledge audit, Knowledge mapping, Knowledge models, Personal KM, Design thinking, Sense making, Explicit and Tacit knowledge.

\section{Methodology}

The methodology in this case is to use student feedback to both evaluate and improve the course delivery. Course Experience Surveys (CES) are independently conducted by the university as a means of collecting anonymous student feedback on all courses. The CES includes free text comments and quantitative five point scale responses to questions. Results for "Overall Satisfaction Index" (OSI) and "Good Teaching Score" (GTS) are calculated as percent scores based on the proportion of students that "agree or strongly agree" with a series of statements and questions. OSI and GTS results for Knowledge Driven Performance are shown in Table 1, with comparisons to the average scores for the School in which the course was operated. This school's scores have consistently been several percent above the average scores for the rest of the University during the time discussed in this article.

Each semester, comments from students through the anonymous Course Experience Surveys (CES), unsolicited emails and feedback on in-class activities were reflected upon and the course adapted over time to increasingly incorporate active learning and focus on social aspects of learning. CES is not performed for the OUA version of the course but, reflective exercises performed in weekly activities, provide rich information about how the course learning is being applied in student workplaces (most virtual students are working part time and studying full time).

The key limitations of this research are that observations are subjective, direct impacts of interventions applied are difficult to measure and there is a chance of cognitive bias in interpreting results. To minimise the impacts of this, the design and approach of the course is actively discussed with students from the beginning, and throughout, the course. They are advised that reflective practice is a key aspect of knowledge management, learning and innovation and that the course is based on the very principles that it is trying to teach them. This is discussed in several of the reflective activities spread throughout the course to reinforce the learning and ensure that principles are being applied and generating the desired outcomes. Some of the feedback comments offered by students reinforce this as a key aspect of their learning experience in the course. 
Active learning approach influence on course design and facilitation

In 2007, this course was delivered in a very traditional style of pedagogy. That is, it was teacher-centered and content-based and was not well received by the students as is shown in Table 1 below. In 2008, a new facilitator restructured the course into facilitated active learning to engage the students through a series of conversations around topics. Between 2008 and 2014, the course continued to evolve though innovative developments that focused on student-centered learning and application of the concepts in the students' own workplaces as much as could be achieved. The industry experiences of the learning facilitator (term used deliberately to highlight the differences to "teacher" or "lecturer") were leveraged to show the value of theory to practice and vice versa.

Although each week there are elements of theoretical content to be covered, the content is used as a stimulus for the conversations that participants use to explore for insights. The content is neither the main focus or purpose of the session. The course operates on the concept of praxis, which combines theory and practice in balanced ways to provide a deeper context and more pragmatic learning (White 2007). Students engage in conversations about the value created by applying the concepts rather than trying to remember the content itself. This innovative and practical method of learning was found to be highly engaging and effective for the students.

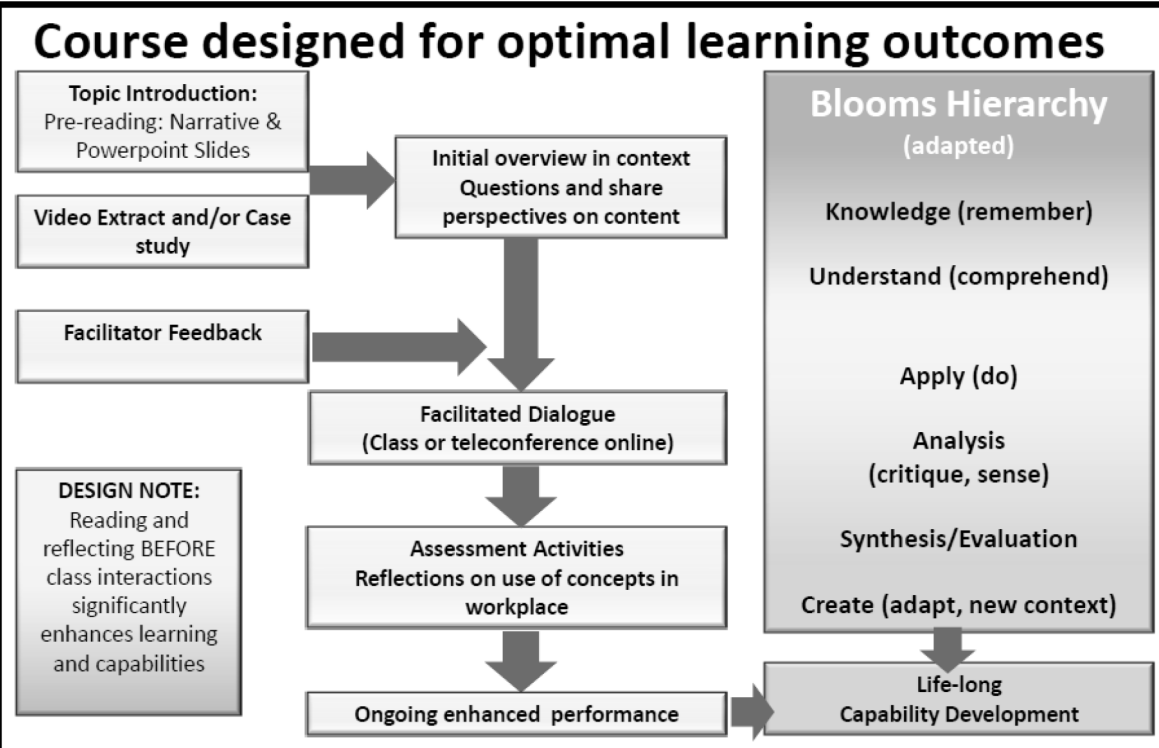

Figure 1: Structure of the active learning cycles deployed in the course for optimal and sustained learning 
Course design changes were introduced to generate "work ready professionals" by engaging students in activities that they would be expected to do in the modern workplace. This direct experience of working with others to leverage diversity of perspectives helps them learn in a richer way. The course also specifically aligns with the RMIT University Graduate Attributes. How it aligns with the MBA program learning outcomes (bolded in the list below) is described immediately after each one:

- Self-management through understanding how to continuously develop through lifelong learning

- Operational leadership through research on real organisations and making proposals for improvement and specific knowledge initiatives to fill gaps

- Contemporary business perspective gained by dealing with complex contemporary organisational challenges

- Analytical \& technical competency developed from analysis of case situations and synthesis of interdependent arguments shared through the collaborative wiki

- Strategic decision making happens every week through the dialogues in class and through the wiki or discussion board interactions

- Corporate responsibility is proactively embedded into the course content with questions and challenges and ethics is included as one of the wiki topics

- Effective communication is reinforced with professional standards expected in both written and oral activities, including assessed role plays where students present costed knowledge initiatives to the "CEO" (teacher) and board (other students).

In doing, so the course has specific learning outcomes that were directly relevant to contemporary knowledge-informed leadership and management practices. It also recognises that the process of learning itself is a significant capability that enhances the performance of professionals over time. Professional capability in the current professional context requires leaders and managers to anticipate more what is likely to happen, make sense of a range of possibilities and then prioritise decisions to optimise outcomes and generate sustainable outcomes. This requires a mature mindset that is comfortable with ongoing learning, complexity and uncertainty.

The idea that education is focused on remembering content is fine if the content is not rapidly changing, but this is not what our graduates need to be successful in their professional futures. To prepare them for a more productive and rewarding career, we need to embed the principles of andragogy (student-centred, teacher-facilitated) into their learning experiences, rather than apply traditional pedagogy (teacher-centred, content-focused) and this 
enables them to approach unknown issues and find ways of dealing with them effectively (applying learning in action for novel situations).

Knowles (1984) described five key features of learners effectively engaged in andragogy style learning defining them as follows:

1) Self-concept: learners are self-directed and self-motivated rather than teacher dependent.

2) Experience: learners leverage the collective experience of all participants through shared challenges and constructive challenges to enrich the collaborative learning.

3) Readiness to learn: learners are actively seeking to develop themselves to be more capable, professionally and socially.

4) Orientation to learning: the learner perceives value in the ability to apply knowledge to immediate contexts. Accordingly they reorientate learning efforts from subject-centred to (real) problem-centred.

5) Motivation to learn: the motivation to learn is internal.

These five principles are explained at the beginning of the course to ensure students understand both the intent of the learning and what the expectations are. Assessment activities are aligned with this through the principles of constructive alignment (Biggs \& Tang 2011) in which learning activities and assessment of them are designed with the learning outcomes in mind. This concept is combined with the objective that the course is developing effective leaders for an unknown future (Snook, Nohria \& Khurana 2012) and to bring together the personal development of the person as a whole as shown in Figure 2. The concept of professional development extending beyond content and towards how we interact with each other has developed from earlier conceptual work of Polanyi (Polanyi \& Grene 1969) and has been extensively discussed more recently by White (2007).

Each week a unit topic theme is introduced through a combination of an introductory topic narrative, a set of slides summarising key concepts, and additional details to fuel discussion including supplementary content (document extract or video) related to the topic.

Course participants are expected to review these materials before the class interactions, as they will be asked to engage in discussion about them. The dialogue works best when all participants are active in constructively challenging the materials and sharing their perspectives of what this means for them and their contexts. In face to face courses, these interactions occur in the classroom and in the virtual version of the course they happen firstly through the discussion forum and subsequently via the interactive dialogues in conferencing sessions using the Learning Management System functions.

This process, depicted in Figure 1, is designed to maximise the value that course participants receive from their investment in their education. The approach is emergent, but grounded in robust learning theory and the 
practical experiences of the course facilitator. Another feature of the learning process is engaging learners in group discussion activities around challenges that occur in the workplace, thereby aligning with problem-based learning approaches (Hung, Jonassen \& Liu 2008). The interaction between members of the classes is critical to the richness of the learning for all involved and is therefore an important element of the assessment.

Class participants are graded on the frequency and quality of their contributions to the learning experiences, both in the live interactions and through their supportive comments and challenges to each other's wiki pages. This is done to reinforce the importance of actively contributing to workplace dialogue and engaging in exchange of perspectives in a professional and constructive manner.

Figure 2 reinforces the importance of aligning learning activities with learning outcomes by applying the theories in practice. This model also highlights the relationship between behavioural aspects of engaging in learning (of both learners and facilitator) and the effectiveness of the learning outcomes.

- Knowledge

- Knowing: understanding, experience

Outcomes

- Skills

- Doing: application of knowledge in context

\section{Development}

\section{- Abilities}

- Being: behaviours, attitudes

\section{Activities}

Assessment

Figure 2. Constructive alignment of activities and assessment to meet learning outcomes and personal and professional development objectives

\section{Findings}

The Course Experience Survey (CES) results demonstrate that students respond very positively to the course approach. They provide further insights into what is good and what can be improved through specific comments in the survey as well as emails and in the interactive wiki. These interactions inspire the course facilitator to continuously improve courses and experiment with alternative activities to keep the course fresh and engaging. Examples of some changes made based on student feedback include doing a pitch of best ideas for each of their companies to share options for other groups, 
recommendation of alternative high performing companies to research, and inclusion of polling for ideas and ranking responses in the online discussions. Ideas and techniques have also been shared with other teaching staff and these courses have seen increased CES scores.

The lower scores for shared classes highlight the challenges of instilling passion in other facilitators to deliver in an interactive way with rich feedback. Sharing the course was necessary as the original facilitator was spread across several other classes and was not able to deliver all components of the course. Similar impacts have been observed in some other shared courses, where increased interactive teaching has improved results, both in this school and also elsewhere (Freeman et al. 2014). Facilitative learning approaches work well when the facilitator is passionate. Whilst knowledge and activities can easily be passed to other facilitators, passion is more difficult to transfer. Student feedback in Table 2 highlights that the engagement level of the facilitator has an effect on their motivation to learn and the effort they invest in the learning and assessment activities as has been reported elsewhere (Albanese \& Mitchell 1993; Boud \& Feletti 1997; Freeman et al. 2014).

The lower OSI score in 2012 occurred primarily for two reasons. Firstly, the change to electronic submission of the CES survey caused a significant reduction in student feedback, making each one a higher proportion of the total. Secondly, in that semester the workload of the facilitator was very high, impacting on the time available to construct detailed feedback for assessments. Feedback is a critical element of learning and is very different to "marking", "corrections" or even "grading". These three activities are focused on assessment to the stated standard and this is important. However, the real learning comes from understanding WHY they received the grade they did, and why not higher or lower. Optimal feedback is balanced between what was delivered well and specific advice on how the submission could have been improved. This provides both encouragement to build confidence and also the foundation for improvement, both of which are essential for enhanced learning outcomes.

Table 1. Course Experience Survey results (student feedback) for Knowledge Driven Performance 2007-2014

\begin{tabular}{|c|c|c|c|c|c|c|c|c|}
\hline Course Experience Survey score & \multirow[t]{2}{*}{07} & \multirow{3}{*}{ 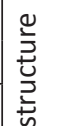 } & \multicolumn{6}{|c|}{ Evolution of the course towards interactivity } \\
\hline Year & & & ‘08 & ‘09 & $' 10$ & '11 & $' 12$ & ‘13 \\
\hline KPD Good Teaching Scale \% & 36 & & 81 & 93 & 94 & 94 & 100 & $* 81$ \\
\hline KDP Overall Satisfaction Index \% & 36 & $\frac{\varrho}{\varrho}$ & 78 & 100 & 100 & 100 & 86 & $* 93$ \\
\hline $\begin{array}{l}\text { School MBA Average GTS \% } \\
\text { School MBA Average OSI \% }\end{array}$ & $\begin{array}{l}70 \\
73\end{array}$ & 气ั山 & $\begin{array}{l}68 \\
69\end{array}$ & $\begin{array}{l}75 \\
76\end{array}$ & $\begin{array}{l}* * 64 \\
* * 74\end{array}$ & $\begin{array}{l}64 \\
69\end{array}$ & $\begin{array}{l}67 \\
69\end{array}$ & $\begin{array}{l}72 \\
79\end{array}$ \\
\hline
\end{tabular}

* Shared teaching class, showing the power of interactive facilitation and use of stories. 
** Major transition year for the school with significant disruption for students.

Note: Scores are percentage of students that agree or strongly agree with statements in an anonymous survey on the quality of teaching or their overall satisfaction with the course.

Examples of student feedback provided through the CES and unsolicited emails are included in Table 2. These highlight students engaged well with the interactive student-centred approach and saw value for their professional development and ongoing learning activities.

Table 2. Student comments supporting the course innovations and learning approach

I keep thinking about KM stuff all the time about how I can improve the process, connectedness etc...

My individual Wiki (assignment 1) prompted me to suggest some fairly radical new approaches within our organisation in regard to how we measure success.

I can see our explicit knowledge base building and most importantly everyone is enjoying the interaction, so I know that it will be a success for the long term. I also learnt a great deal from reading all the students' posts and I'm in deep admiration of some of the fine minds in this course.

Thanks for your teaching ... I can tell you ... I'm actually incorporating many of the KM practises learnt in this course into this business. So thank you. I know your task was enormous and I appreciate all that you have provided in KM.

It's been a pleasure to be part of your class. I hope students will continue to have the opportunity to learn from you and see the passion you have for the subject in the coming semesters. The influence our teachers have on our capacity to learn is highly underrated.

Thank you. I appreciate the feedback. Of all the subjects undertaken since commencing my degree, this has interested me the most. I am in the process of starting my own network and consulting business and would like to chat to you about frameworks, once I have finalised.

You engaged us not only during face-to-face sessions but also via emails, Skype, etc. I enjoyed the way you used simple examples or small games to demonstrate different elements of leadership as well as what we should improve to be better leaders. Group work and discussions were all very informative and knowledge-driven. Wiki site and TurnItIn ${ }^{\circledR}$ voice feedback were new and collaborative tools which I found very useful and effective.

I was very grateful to receive your constructive and thorough feedback on every assignment. As you can see, I learnt and tried to improve my work from your valuable feedback/comments.

I like this course for its highly interactive methodology and learning experience... made the course interesting, informative and enjoyable. Arthur's personal interaction on a professional level is what keeps us going and inspired.

\section{Observations and discussion}

The results highlight the benefits to the students of implementing an interactive active learning approach. Feedback has consistently been very high, even when other external factors have affected the learning environment (such as teachers less experienced in the andragogy approach, major restructuring of the school and changing the CES feedback submissions 
to online). Adopting an interactive 'adult learning' approach helps students to gain a stronger sense of the meaning of the content, the theories and the contexts where KM is applied. It also enables richer dialogue and interactions between students.

Actively engaging learners in 'Peer to Peer' learning similar to that described by Knowles, Holton and Swanson (2011) has taken the learning experience to a higher level, resulting in deeper and wider understanding of the importance of each topic and the relationships between them. Student feedback shows that the way students are engaged in the KDP course motivates them to participate more actively and generates better individual learning outcomes. Another indication that the students valued the class interactions is that class attendance remained very high through the semester, despite the classes being recorded and being made available to listen to at a later time. This, and student feedback comments received, indicate that they enjoyed the nature of their engagement with their learning peers.

One advantage in interactive learning environments is that it enables participants to capitalise on the diversity of cultural backgrounds and destinations (MBA students at RMIT University typically come from many Asian and some European, American and African nations). This reinforces that learning quality is enriched through exploring options in a social discovery process of sharing perspectives to create a better future. Knowledge Driven Performance has an internationalised curriculum with case studies from many countries to enable students to engage with a range of contexts and include their own perspectives, as endorsed by Biggs and Tang (2011).

Deployment of activities such as case studies, games and role plays to explore the best and worst outcomes of complex scenarios assist with reinforcing the benefits of generating options for future realistic scenarios, rather than considering 'theoretical textbook' solutions. After each activity, participants reflect on what learning has occurred, reinforcing the activity's purpose and ensuring understanding is optimised. Critically reflecting on their peers' perspectives develops each student's capability to challenge concepts and context, and ultimately to become more capable professionals. Students develop confidence to think for themselves about decisions and actions in their workplaces. This reflection and skills development directly contributes to developing professional capability and personal strengths, aligning with McIntosh's (2010) recommendations for reflective practitioners.

Applying the andragogy principles helps build and leverage social capital and generates opportunities for each student to individually interact with the learning facilitator and their peers, through both face-to-face and virtual connections. This teaching strategy creates an identity and confidence that 
resonates beyond their time in the KDP course. The shared assignments in the wiki reinforce these interactions between students - there, they collaborate to generate a comprehensive encyclopaedia on a range of relevant topics and to share their own 'professional profile'. They regularly interact with each other through this platform which they identify as 'their own space' and many of the students remain in contact with the learning facilitator and each other beyond the course.

This research reinforces the claim that moving away from teacher and content-focused presentation to student-centred dialogue about content in the student's own contexts and experiences, produces richer learning and higher quality student submissions. Quality of student work submitted is further enhanced because the early assessments are open for all participants to see, which highlights the quality range and the gap between their work and others. More importantly, the collaborative learning environment enables all students to learn from all other student's work, as it is available to them throughout the rest of the course.

\section{Conclusion}

Experiences with this course demonstrate that interactive and social learning increases the learning outcomes and the richness of the learning experience. The ultimate desired outcome of effective teaching is that students develop deep and rich insights into a wide range of factors that influence how they interact and perform in their workplaces. This case demonstrates that student experiences in the Knowledge Driven Performance course have been positive and motivated some of them to implement changes in their workplaces within the learning period. It is hoped that these experiences will enable them to deal more effectively with uncertainty and look towards developing better future solutions. They emerge with a mindset that enables them to move from 'what is' to explore 'what is possible'. This mind-shift and an enhanced motivation to be lifelong learners, places them well to succeed in their professional pursuits through the innovative application of capabilities and knowledge to stimulate personal, team and organisational performance.

In the end, the real voice of authority for the quality the learning facilitator provides is that of the students themselves. This is best summarised by one student's statement highlighting the value of experience and style of the facilitator: "Your knowledge, time, investment and inspiration have made it one of the best quality and inspiring courses I have ever learnt. Thank you very much." 


\section{Acknowledgements}

Thanks to the students of "Knowledge Driven Performance" over the last 7 years. You have been a critical part of the journey and we have all learnt from each other. Thanks to those who have remained in touch and sent through your experiences of your ongoing learning journey. Thanks also to members of the actKM and Melbourne Knowledge Management Leadership Forum communities who have provided a robust sounding board for ideas and concepts over the last decade.

\section{References}

Albanese, M.A. \& Mitchell, S.M. (1993). Problem-based Learning: a Review of Literature on Its Outcomes and Implementation Issues. Academic Medicine, 68(1), pp. 52-81.

Bedford, D.A.D. (2013). Knowledge Management Education and Training in Academic Institutions in 2012. Journal of Information \& Knowledge Management, 12(4), pp. 1-16.

Biggs, J. \& Tang, C. (2011). Teaching for Quality Learning at University, 4th edn, Society for Research into Higher Education \& Open University Press. Maidenhead: UK.

Bloom, B.S., Hastings, J.T. \& Madaus, G.F. (1971). Handbook on Formative and Summative Evaluation of Student Learning. McGraw-Hill Book Company. New York, NY: USA.

Boud, D. \& Feletti, G. (eds). (1997). The Challenge of Problem-based Learning. Kogan Page, London.

Cavaleri, S., Seivert, S. \& Lee, L.W. (2005). Knowledge Leadership The art and science of the knowledge based organisation. Elsevier ButterworthHeinemann. Oxford: UK.

Chua, A. \& Lam, W. (2005). Why KM projects fail: a multi-case analysis. Journal of Knowledge Management, 9(3), pp. 6-17.

Edmondson, A.C. (2011). Strategies for Learning from Failure,. Harvard Business Review, 89(4).

Freeman, S., Eddy, S.L., McDonough, M., Smith, M.K., Okoroafor, N., Jordt, H. \& Wenderoth, M.P. (2014). Active learning increases student performance in science, engineering and mathematics. Proceedings of the National Academy of Sciences of the United States of America.

Hung, W., Jonassen, D.H. \& Liu, R. (2008). Problem-Based Learning. In JM Spector \& MD Merrill (eds.), Handbook of research on educational communications and technology, 3rd edn. Lawrence Earlbaum Associates. New York, pp. 485-506.

Knowles, M.S. (1984). Andragogy in Action. Applying modern principles of adult education, Jossey Bass. San Francisco: CA, USA. 
Knowles, M.S., Holton, E.F. \& Swanson, R.A. (2011). The Adult Learner. The definitive classic in adult education and human resource development. Butterworth-Heinemann: Oxford, UK.

Lambe, P. (2011). The unacknowledged parentage of knowledge management. Journal of Knowledge Management, 15(2), pp. 175-97.

Malhotra, A., Majchrzak, A. \& Rosen, B. (2007). Leading Virtual Teams., Academy of Management Perspectives, 21(1), pp. 60-70.

Mclntosh, P. (2010). Action research and reflective practice. Creative and visual methods to facilitate reflection and learning. Routledge: London \& NY

Mosier, K.L. \& Fischer, U.M. (eds). (2011). Informed by Knowledge: Expert Performance in Complex Situations. Expertise: Research and Applications Series, Psychology Press: New York, USA.

Müller, R. \& Turner, J.R. (2010). Project-Oriented Leadership, Advances in Project Management, Gower Publishing Limited Surrey.

Polanyi, M. \& Grene, M. (1969). Knowing and being: Essays by Michael Polanyi. University of Chicago Press: Chicago.

Raelin, J.A. (2006). Does Action Learning Promote Collaborative Leadership? Academy of Management Learning \& Education, 5(2), pp. 152-68.

Shelley, A.W. (2009). Being a successful knowledge leader. Ark Group: North Sydney.

Snook, S.A., Nohria, N.N. \& Khurana, R. (2012). The Handbook for Teaching Leadership: Knowing, Doing, and Being. Sage: Los Angeles.

White, J. (2007). Knowing, Doing and Being in Context: a Praxis-oriented Approach to Child and Youth Care. Child Youth Care Forum, 36, pp. 22544.

Zuber-Skerritt, O. (2002). a Model for Designing Action Learning and Action Research Programs. The Learning Organization, 9(4), pp. 143-9.

\begin{abstract}
Abstrakt (in Polish)
Innowacje dotyczqce sposobu prowadzenia kursu Zarzq̨dzania Wiedza dla studentów studiów podyplomowych pozwoliły na osiągnięcie lepszych wyników nauczania i zwiększyły zaangażowanie studentów w kurs. Informacje zwrotne uzyskane od studentów pokazuja, że preferujq oni wspólne, aktywne uczenie się, pozwalajqce im na bogatszy wglqd w tworzenie wiedzy i stosowanie jej do osiqgnięcia innowacji i wartości. Kurs stosuje podejście andragogiczne, w którym studenci współdziałajq w cotygodniowym dialogu dotyczq̨cym ich doświadczeń zwiq̨anych z treściq kursu zamiast po prostu uczyć się tej treści. Podejście to łączy myślenie systemowe, praktykę uczenia i aktywne uczenie w celu zbadania współzależności między tematami oraz ich wpływem na rzeczywiste sytuacje. Kurs zachęcił studentów do zastosowania tych idei w ich miejscach pracy.
\end{abstract}

Słowa kluczowe: wiedza, uczenie, edukacja, myślenie systemowe, myślenie projektowe, aktywne uczenie, współzależność, wiedza własna. 


\section{Biography}

Dr Arthur Shelley is a capability and knowledge strategy consultant, educator and author of several journal articles, book chapters and two books: Being a Successful Knowledge Leader and The Organizational Zoo, a Survival Guide to Workplace Behaviour. He has a Masters in Microbiology/Biochemistry and a PhD in Project Management. He works with corporate, non-profit and government teams to enhance outcomes from projects and knowledge based initiatives. He has been a judge for the Knowledge Awards for the ActKM forum and the Singapore Information and Knowledge Management Society. In his former role of Global Knowledge Director at Cadbury Schweppes, he successfully initiated and facilitated virtual global communities to leverage knowledge, exchange ideas and increase productivity. Arthur is the founder of Intelligent Answers, the leader of the RMIT University MBA Student Mentoring program and the coordinator of the Knowledge Driven Performance course in the MBA and the Knowledge Management and PM Leadership courses in the Master of Project Management. He co-facilitates the Melbourne KM Leadership Forum and the Organizational Zoo Ambassadors Network (a peer mentoring group interested in using metaphor to creatively leverage behavioural diversity). Intelligent Answers and RMIT University, Melbourne, Australia. Graduate School of Business and Law, RMIT University, GPO Box 2476, Melbourne VIC 3001 Australia. Tel. (61) 413047 408. Tel. (61) 413 047 408, Email: Arthur@IntelligentAnswers.com.au. Skype: Arthur.Shelley. Linkedln: http://www.linkedin.com/profile/view?id=4229168. 
